\title{
Sphaerospora scardinii n. sp. (Myxosporea: Sphaerosporidae) observed in the kidney of rudd Scardinius erythrophthalmus
}

\author{
M. El-Matbouli, R. W. Hoffmann \\ Institute of Zoology and Hydrobiology, University of Munich, Kaulbachstraße 37, W-8000 München 22, Germany
}

\begin{abstract}
Sphaerospora scardinii n. sp. is described from the kidney of rudd Scardinius erythrophthalmus obtained from the river Main. Three stages of development were observed: intracellular trophozoites consisting of one uninucleate cell in epithelial cells of the ureter, round to oval extrasporogonic stages $(17.49 \pm 2.29 \mu \mathrm{m}$ in size $)$ in the lumen of the ureter and pseudoplasmodial sporogonic stages (elongated to irregular in shape, $20.27 \times 12.32 \mu \mathrm{m}$ ) in the lumen of kidney tubules. One or two subspherical spores $(6.01 \mu \mathrm{m}$ length, $5.79 \mu \mathrm{m}$ width) developed within the surrounding pseudoplasmodium. Thin valves surrounded 2 spherical polar capsules $(2.26 \times 2.14 \mu \mathrm{m})$ which contained a polar filament with 4 to 5 coils.
\end{abstract}

\section{INTRODUCTION}

Many species of the genus Sphaerospora Thelohan, 1892 are known to have pathogenic potential in various fish hosts. These species have recently attracted special attention as agents of sphaerosporosis affecting kidney, swimbladder and blood, such as Sphaerospora renicola (Dykova \& Lom 1982), or gills, such as Sphaerospora molnari (Lom et al. 1983), in common carp. The first Sphaerospora found to be pathogenic was $S$. tinca Plehn, 1925 infecting the head kidney of tench Tinca tinca.

To our knowledge 43 species of the myxosporean genus Sphaerospora are known. Arthur \& Lom (1985) listed 36 species, of which most have been described from the lumina of the kidney tubules and urinary bladder of freshwater fishes. Since then, 7 other renal species have been described: $S$. diminuta, from the renal tubules of pumpkinseed Lepomis gibbosus (Li \& Desser 1985); S. truttae in brown trout Salmo trutta (Fischer-Scherl et al. 1986); S. paulini and S. hankai from the renal tubules of creek chub Semotilus atromaculatus and brown bullhead Ictalurus nebulosus respectively (Lom et al. 1989); S. ictaluri in channel catfish Ictalurus punctatus (Hedrick et al. 1990); S. colomani in sterlet Acipenser ruthenus (Baska 1990); and $S$. epinepheli in grouper Epinephelus malabaricus
(Supamattaya et al. 1991). Lom et al. (1985) reported Sphaerospora spp. from renal tubules of roach Rutilus rutilus in a fish pond near Bohemia. This infection was so light that the material was insufficient for the authors to describe the species adequately.

Most species of Sphaerospora are known only from a single host. The species appear to be strictly hostspecific, e.g. S. molnari and S. renicola are parasitic in Cyprinus carpio, and $S$. tincae is known only from Tinca tinca. Some Sphaerospora species are characterized by vegetative reproduction in the blood and tissues of other organs. In this paper we describe Sphaerospora scardinii n. sp. from the kidney of rudd Scardinius erythrophthalmus.

\section{MATERIALS AND METHODS}

In a parasitological survey during February and March 1992 rudd Scardinius erythrophthalmus and roach Rutilus rutilus were collected from the Main River near Würzburg, Germany. In this study 10 rudd and 15 roach (50 to $150 \mathrm{~g}, 18$ to $23 \mathrm{~cm}$ ) were examined. For histological studies, tissue samples from gills, kidney, liver, spleen, heart, muscle, gut and brain were fixed in $5 \%$ buffered formaldehyde and embedded in Paraplast or Historesin. Sections were stained with 
H\&E, Giemsa's solution, and Toluidine Blue and using the Periodic Acid-Schiff (PAS) reaction.

For examination of fresh material, portions of each organ were sampled and examined in fresh mounts by light microscopy. Morphology of spores and of developmental stages was observed in fresh mounts. Dimensions of these stages were determined using a Leitz. Dialux 20 light microscope equipped with an ocular micrometer and assisted by a computer (model PET $300 \mathrm{I}$; Leitz). Blood smears and kidney impressions were air-dried, fixed in methanol and stained with Giemsa's solution.

\section{DESCRIPTION}

\section{Sphaerospora scardinii n. sp. (Fig. 1)}

Host: Rudd Scardinius erythrophthalmus.

Locality: The river Main, near Würzburg, Germany.

Location: Lumen of the kidney tubules, distal and proximal tubules, collecting ducts and ureter.

Prevalence: 7 of 10 host specimens examined.

Developmental stages: Extrasporogonic stages were round to oval ( $\mathrm{n}=20$, mean diameter $=17.49 \pm$ $2.29 \mu \mathrm{m})$. They contained numerous highly refractile granules and were found only in the ureter of the kidney.

Sporogonic stages: These were composed of 6 or 12 cells within a pseudoplasmodium in the lumen in the kidney tubules. One or two spores developed within each pseudoplasmodium.

Spore characteristics: Spores were almost spherical with a somewhat projecting anterior pole and enveloped by a shell composed of 2 valves connected by a clearly visible suture. At the posterior pole of the spore 3 to 4 fine ridges were seen. Mean length of the spore $(n=20)$ was $6.01 \pm 0.58 \mu$ m, mean width $5.79 \pm$ $0.26 \mu \mathrm{m}$. At the apical end of the spore were 2 almost spherical polar capsules with a polar filament showing 4 to 5 coils. Mean length of polar capsules was $2.26 \pm$ $0.28 \mu \mathrm{m}$, mean width $2.14 \pm 0.18 \mu \mathrm{m}$.

\section{RESULTS}

From a total of 10 rudd, 7 were parasitized by Sphaerospora scardinii n. sp. Developmental stages and mature spores were found in fresh preparations, in Giemsa-stained imprints from all parts of the kidney and in tissue sections. Kidneys of infected rudd appeared to be slightly swollen. Histologically a hyperplasia of lower urinary ducts could be seen. In PASstained sections, mature spores and pseudoplasmodia exhibited PAS-positive granules in the cytoplasm and in the shell valves. In infected rudd, $S$. scardinii was found exclusively in the kidney. No other organs were infected. Infections with $S$. scardinii or with any other Sphaerospora species were absent from all roach examined.

\section{Extrasporogonic stages}

In infected rudd the lumen of the ureter and collecting ducts of the kidney were filled with trophozoite developmental stages (Figs. 2 \& 3). Trophozoites were round in shape, up to $17 \mu \mathrm{m}$ in size, and contained numerous refractile granules in the cytoplasm. Rounded primary cells included up to 8 secondary cells. In infected fish the ureter epithelial cells had proliferated and intracellular trophozoites were located in the apical region of the cells. In histological sections trophozoites were seen singly in the epithelial cells (Fig. 4).

\section{Sporogonic stages}

Pseudoplasmodia in various stages of development were observed (Fig. 5) within the lumina of the proximal tubule. They were elongated or irregular in shape, up to $23 \mu \mathrm{m}$ in length and $15 \mu \mathrm{m}$ in width, with numerous refractile granules in the cytoplasm. These pseudoplasmodia ranged from simple unicellular stages to stages with up to 12 cells within the surrounding pseudoplasmodium. In the lumina of the kidney tubules both mono- and disporic pseudoplasmodia were observed in fresh preparations (Figs. 6 \& 7) and stained sections (Fig. 8).

Mature spores (Figs. 1 \& 7) were subspherical, had a pointed anterior end and contained 2 spherical polar capsules that opened towards the anterior end of the spore near the sutural ridge. Spore length was $6.01 \pm$ $0.58 \mu \mathrm{m}$, width $5.79 \pm 0.26 \mu \mathrm{m}(\mathrm{n}=20)$. The suture of the 2 valves protruded only slightly anteriorly Both polar capsules were of equal size with a length of 2.26 $\pm 0.28 \mu \mathrm{m}$ and a width of $2.14 \pm 0.18 \mu \mathrm{m}$. The polar filament was coiled 4 to 5 times, wound almost perpendicularly to the longitudinal axis of the capsule.

In blood smears no myxosporean developmental stages were observed.

\section{DISCUSSION}

The Sphaerospora scardinii detected in the kidney of rudd in this study are the first to be reported in detail from rudd. A similar Sphaerospora sp. in rudd was 

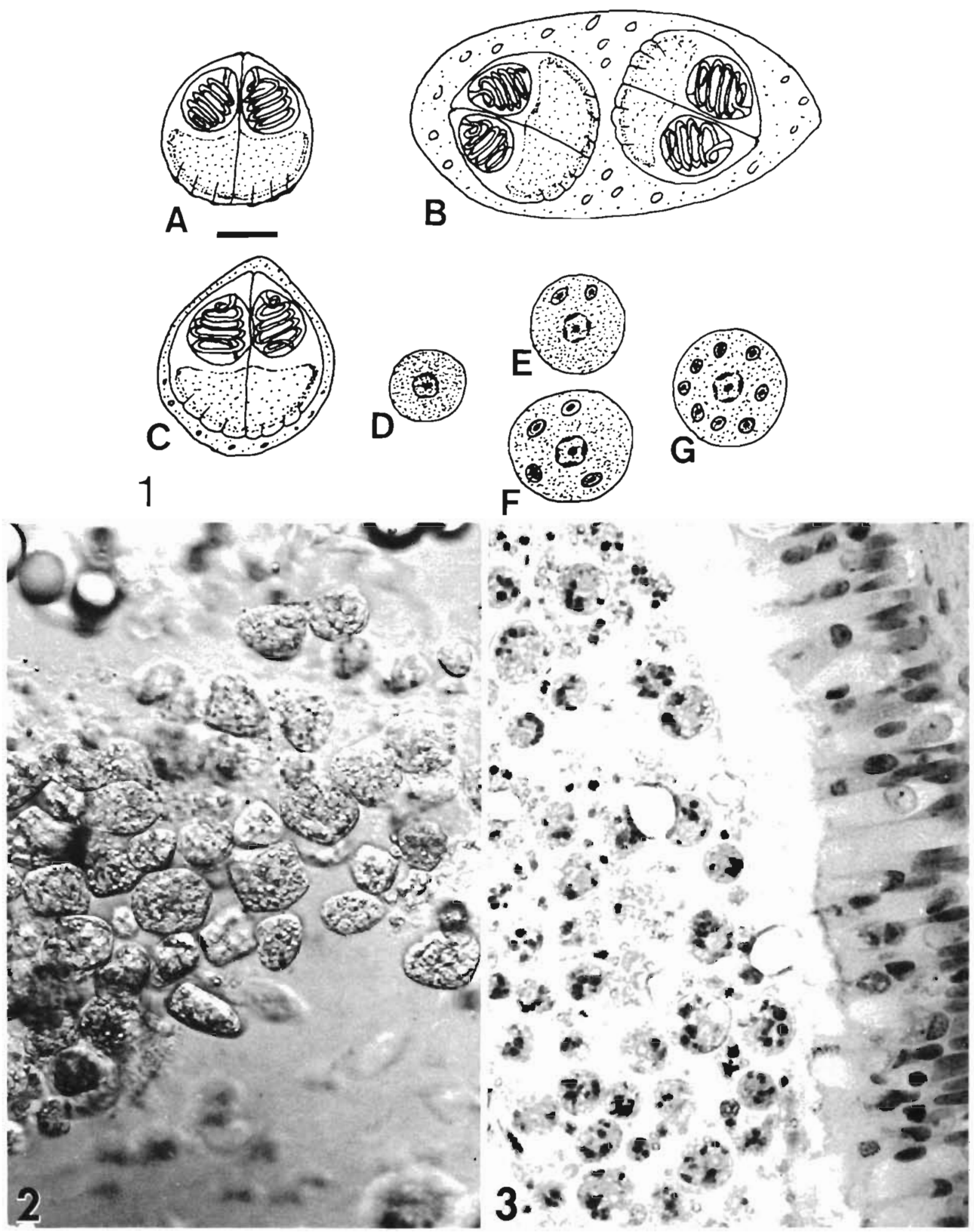

Figs. 1 to 3. Sphaerospora scardinii infecting Scardinius erythrophthalmus. Fig. 1. Line drawings of various stages. (A) Mature spore; (B) disporic pseudoplasmodium; (C) monosporic pseudoplasmodium; (D to J) extrasporogonic stages found in the lumen of the ureter. Scale bar $=2.5 \mu \mathrm{m}$. Fig. 2. Extrasporogonic stages detected in the lumen of the ureter. Squash preparation, unstained, $\times 600$. Fig. 3. Histological section with extrasporugunic slages in the lumen of ureter $H \& E_{1} \times 600$ 

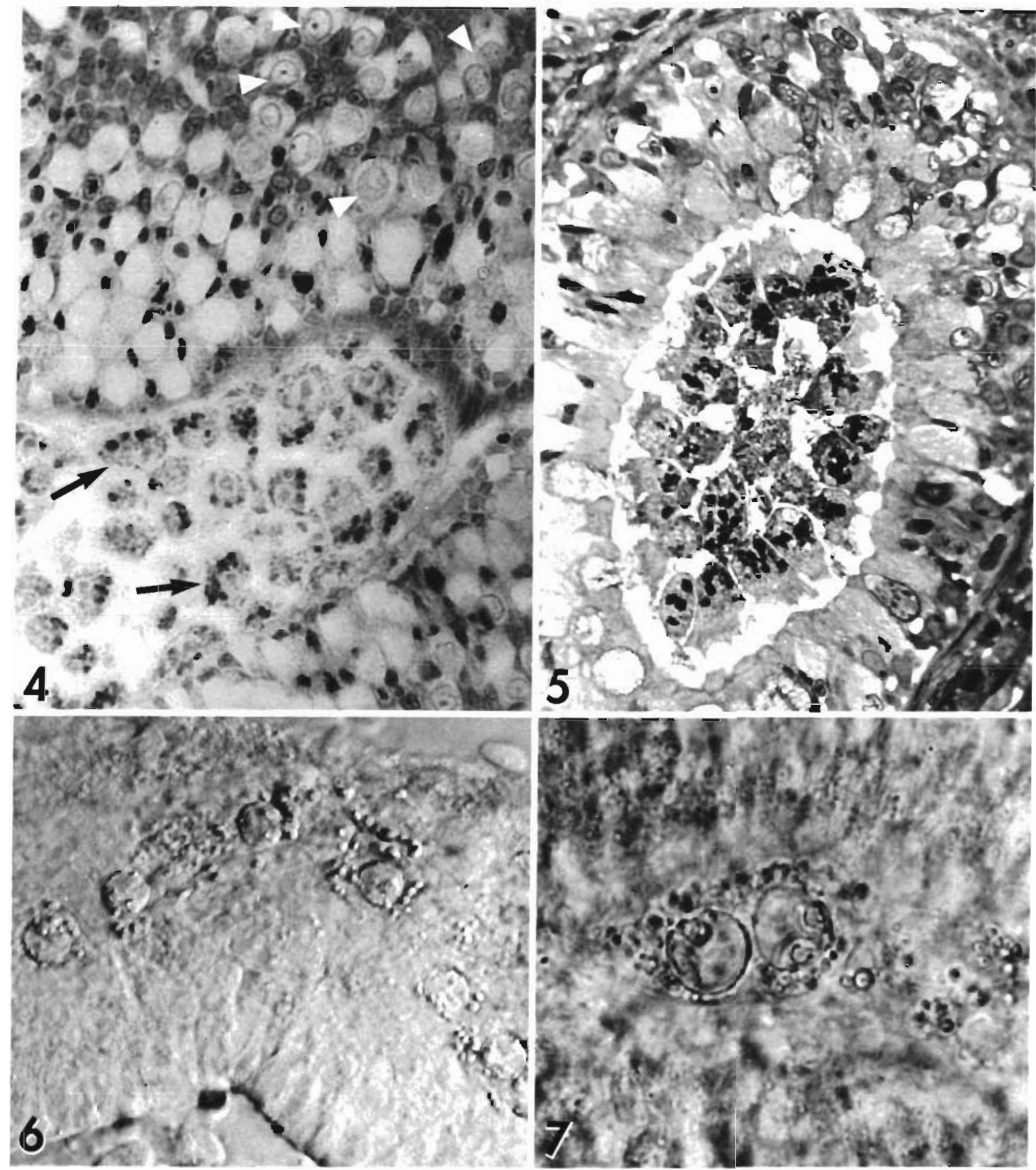

Figs. 4 to 7 Sphaerospora scardinii infecting Scardinius erythrophthalmus. Fig. 4. Ureter with uninucleated trophozoite cells in epithelium (arrowheads) and coelozoic stages in the lumen (arrows). H\&E, $\times 600$. Fig. 5. Infected proximal tubule; the lumen is filled with pseudoplasmodia. Giemsa, $\times 600$. Fig. 6. S. scardinii in the lumen of a kidney tubule; note monosporous pseudoplasmodia with mature spores. Fresh preparation, phase contrast, $\times 930$. Fig. 7 . Disporic pseudoplasmodium with many refractile granules in the lumen of a kidney tubule. Fresh preparation, $\times 1500$ 
Fig. 8. Sphaerospora scardinii infecting Scardinius erythrophthalmus. Mature spores (arrows) in the lumen of renal tubules. Giemsa, $\times 930$

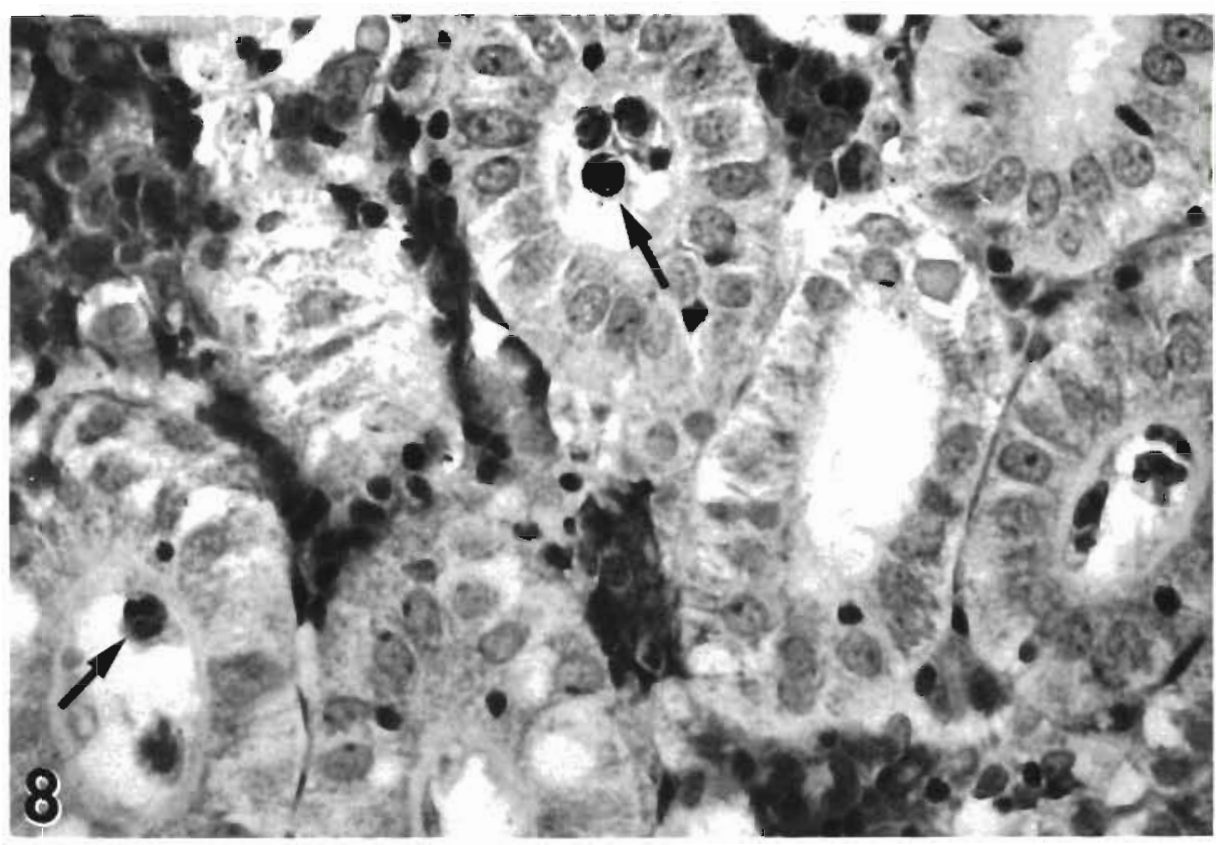

mentioned by Hanjavanit (1991) from Ireland, but a detailed description which would have allowed an exact comparison to our material was not provided. The spores of $S$. scardinii are similar to those described from other species of fish, but their shape, size, host and mono- and disporic development distinguish them from other known sphaerospores. A comparison with other species of Sphaerospora (Table 1) from the kidneys of freshwater fish indicated that $S$. scardinii differs from them with respect to dimensions of spores and polar capsules, the number of coils of the polar filament and the occurrence of both mono- and disporous development. Sphaerospora species infecting kidney tubules of fishes of the subfamily Leuciscinae include S. poljanski Kulemina, 1969, S. rota Zaika, 1961 and S. minima Kashkowsky, 1974 (Shulman 1984). S. poljanski and $S$. rota differ from $S$. scardinii in having much larger polar capsules as well as spores (Table 1). Further, mature spores of both those species have no fine ridges at the posterior pole, which are clearly discernible in $S$. scardinii. The dimensions of $S$. minima (from Rutilus rutilus) are comparable to those of $S$. scardinii, but its shape differs clearly. Compared with spores of $S$. scardinii, which are almost spherical, those of $S$. minima are pyriformic with a narrow anterior end. According to our own unpublished observations on S. minima, the developmental stages of this species clearly diverge in size, shape and location in the kidney from those of $S$. scardinii. Furthermore roach living in the same river as the rudd infected with $S$. scardinii showed no sign of Sphaerospora infection. The presence of both monoand disporic pseudoplasmodia in S. scardinii also dis- tinguished them from S. minima, which have only disporic pseudoplasmodia. Lom et al. $(1983,1985)$ redefined the genus Sphaerospora and stated that the pseudoplasmodia generally are mono- or disporous according to the species. S. scardinii is the first species from a freshwater fish to have shown both mono- and disporic pseudoplasmodia. However, Supamattaya et al. (1991) recently described $S$. epinepheli from kidney tubules of a grouper from marine and brackish waters, which also developed both mono- and disporic pseudoplasmodia.

In addition our material showed that the development of Sphaerospora scardinii includes an early intracellular stage which occurs only in epithelial cells of the ureter. In each epithelial cell one mononucleated trophozoite develops (Fig. 4). Furthermore, the extrasporogonic stages of $S$. scardinii observed in the lumina of the ureter seems to be a characteristic feature in the development of this species. These stages, with diameters up to $17 \mu \mathrm{m}$, were very similar in shape and structure to those described from the blood of cyprinids infected by other sphaerosporeans (Csaba 1976, Molnar 1984, Lom et al. 1985). However, it cannot be determined by light microscopy whether secondary cells of $S$. scardinii also contain tertiary cells as observed in the stages from cyprinid blood.

Molnar (1988) described the development of $M y x-$ obilatus legeri in 10 cyprinid fishes. In rudd, the author found intracellular developmental stages and coelozoic plasmodia of this myxosporean in the lumen of renal tubules. Plasmodia and intracellular trophozoites of $M$. legeri were identical in morphology to those of 
Table 1. Comparison of Sphaerospora scardinii n. sp. with some related Sphaerospora spp. L: length; W: width; all dimensions in $\mu \mathrm{m}$

\begin{tabular}{|c|c|c|c|c|c|c|c|c|}
\hline \multirow{2}{*}{ Parasite (Host\} } & \multirow{2}{*}{$\begin{array}{l}\text { Infection } \\
\text { locus }\end{array}$} & \multicolumn{2}{|c|}{ Spore } & \multicolumn{2}{|c|}{ Polar capsule } & \multirow{2}{*}{ No. of coils } & \multicolumn{2}{|c|}{ Pseudoplasmodia } \\
\hline & & Range & Mean & Range & Mean & & Range & Mean \\
\hline & & & & & & & \multicolumn{2}{|c|}{ Mono or disporic } \\
\hline S. scardinii & Kidney & $L: 5.97-7.25$ & 6.01 & L: $1.80-2.93$ & 2.26 & \multirow{2}{*}{$4-5$} & L: $\quad 10.27-23.64$ & 20.27 \\
\hline $\begin{array}{l}\text { (Scardinius } \\
\text { erythrophthalmus) }\end{array}$ & Tubules & $W: 5.31-6.30$ & 5.79 & $W: 1.82-2.41$ & 2.14 & & $W: \quad 8.44-15.20$ & 12.32 \\
\hline $\begin{array}{l}\text { S. renicola } \\
\text { (Cyprinus carpio) }\end{array}$ & $\begin{array}{l}\text { Kidney } \\
\text { Tubules }\end{array}$ & $\begin{array}{c}\text { L: } \quad 6-8 \\
W: 6.4-8.3\end{array}$ & $\begin{array}{l}7.3 \\
7.2\end{array}$ & $\begin{array}{l}\text { L: } 1.7-2.3 \\
\text { W: } 1.3-1.6\end{array}$ & $\begin{array}{l}2 \\
1.45\end{array}$ & $3-5$ & \multicolumn{2}{|c|}{ Up to $20 \mu \mathrm{m}$ in size } \\
\hline & & & & & & & \multicolumn{2}{|c|}{ Disporic } \\
\hline S. truttae & Kidney & $\mathrm{L}: \quad 6.58-8.68$ & 6.84 & $\mathrm{~L}: 1.8-2.5$ & 2 & \multirow[b]{2}{*}{4} & - & - \\
\hline (Salmo trutta) & Tubules & W: $8.22-8.81$ & 8.81 & - & - & & - & - \\
\hline Sphaerosporasp. & Kidney & - & L: 8.5 & - & $\mathrm{L}: 3.5$ & \multirow{2}{*}{3} & \multirow{2}{*}{\multicolumn{2}{|c|}{$\begin{array}{c}\text { Disporic } \\
\text { Lp to } 14 \text { in size }\end{array}$}} \\
\hline (Rutilus ritilus) & Tubules & - & $W: 8.2$ & - & $W \cdot 2 \cdot 9$ & & & \\
\hline S. tincae & Head & $\mathrm{L}: 7-8.9$ & 8 & - & L: 2.7 & \multirow{2}{*}{$3-4$} & \multirow{2}{*}{\multicolumn{2}{|c|}{$\begin{array}{c}\text { Disporic } \\
\text { Up to } 18 \mu \mathrm{m} \text { in size }\end{array}$}} \\
\hline (Tinca tinca) & Kidney & $W: 6-7.7$ & 7 & - & $W: 2.5$ & & & \\
\hline S. minima & Kidney & L: $6-7.7$ & - & $\mathrm{L}: 2.8-3$ & - & - & - & - \\
\hline (Rutilus rutilus) & Tubules & W: $5.4-6$ & - & $W: 2.3-2.8$ & - & - & - & - \\
\hline S. poljanskii & Kidney & L: $9.5-10$ & - & L: $\quad 3-4$ & - & - & - & - \\
\hline (Rutilus rutilus) & Tubules & $W: 9-10$ & - & $W: 2.5-3$ & - & - & - & - \\
\hline $\begin{array}{l}\text { S. rota } \\
\text { (Brachymystax lenox, } \\
\text { Leuciscus leuciscus, } \\
\text { Cobitis taenia) }\end{array}$ & Kidney & $\mathrm{L}: 8.4-11$ & - & $W: 4.2-5.6$ & - & - & - & - \\
\hline
\end{tabular}

Sphaerospora scardinii; in addition, the extrasporagonic stages of both species displayed some similarity in shape, but there were differences in morphology.

During our observations no stages could be detected in the blood or in the glomerulus of infected rudd, but the low number of fish examined did not allow us to establish whether blood-stages occur or not. No effects on kidney tubules were apparent during the sporogonic stages of development (Figs. $5 \& 8$ ). However, the intracellular trophozoites in the ureter elicited a proliferation of the epithelial cells. A similar but more serious reaction was reported from the swimbladder of carp infected with Sphaerospora renicola (Molnar 1984).

The mode of transmission of all sphaerospores described to date is still unknown. However, several species of the family Myxobolidae are known to be transmitted by oligochaetes as intermediate hosts (Wolf \& Markiw 1984, El-Matbouli \& Hoffmann 1989, Kent et al. 1991, Ruidisch et al. 1991, El-Matbouli et al. 1992). Presently, studies are in preparation to examine the ultrastructure of $S$. scardinii as well as the mode of infection.

Acknowledgements. This study was supported by the Deutsche Forschungsgemeinschaft (grant DFG HO645/8-1). We also thank Mrs C. Vogt and Ms E. Wanschura for excellent technical assistance.

\section{LITERATURE CITED}

Arthur, J. R., Lom, J. (1985). Sphaerospora araii n. sp. (Myxosporea: Sphaerosporidae) from the kidney of a longnose skate (Raja rhina Jordan and Gilbert) from the pacific Ocean off Canada. Can. J. Zool. 62: 2902-2906

Baska, F. (1990). Chloromyxum inexpectatum n. sp. and Sphaerospora colomani n. sp. (Myxozoa: Myxosporea), parasites of the urinary system of the sterlit, Acipenser ruthenus. Syst. Parasitol. 16: 185-193

Csaba, G. (1976). An unidentifiable extracellular protozoan parasite from the blood of carp. Parasitol. Hung. 9: 21-24

Dykova, I., Lom, J. (1982). Sphaerospora renicola n. sp., a myxosporean from carp kidney and its pathogenicity. $Z$. ParasitenKde. 68: 259-268

El-Matbouli, M., Fischer-Scherl, T., Hoffmann, R. W (1992) Transmission of Hoferellus carassii Achmerov, 1960 to goldfish (Carassius auratus) via an aquatic oligochaete. Bull. Eur. Ass. Fish Path. (in press)

El-Matbouli, M., Hoffmann, R. W. (1989). Experimental transmission of two Myxobolus spp. developing bisporogeny via tubificid worms. Parasitol Res. 75: 461-464

Fischer-Scherl, T., El-Matbouli, M., Hoffmann, R. (1986). A new Sphaerospora sp. in brown trout (Salmo trutta $\mathrm{m}$. fario) in Germany. Bull. Eur. Ass. Fish Path. 6: 16-19

Hanjavanit, C. (1991). Squamous cell carcinoma in rudd, Scardinius erythrophthalmus (L.). Ph.D. thesis, University College, Cork, Ireland

Hedrick, R. P., McDowell, T., Groff, J. M. (1990). Sphaerospora ictaluri n. sp. (Myxosporea: Sphaerosporidae) observed in the kidney of channel catfish, Ictalurus punctatus Rafinesque. J. Protozool. 37: 107-112 
Kent, M. L., Whitacker, D. J., Margolis, L. (1991). Experimental transmission of Myxobolus arcticus to sockeye salmon using an oligochaete Eclipidrilus sp. (Lumbriculidae) Amer. Fish. Soc. Fish Health Sec., Newsletter 2: 3-4

Li, L., Desser, S. S. (1985). The protozoan parasites of fish from two lakes in Algonquin Park, Ontario. Can. J. Zool. 63: 1846-1858

Lom, J., Desser, S. S., Dykova, I. (1989). Some little-known and new protozoan parasites of fish from lake Sasajewun, Algonquin Park, Ontario. Can. J. Zool. 67: $1372-1379$

Lom, J., Dykova, E., Pavlaskova, M., Grupcheva, G. (1983). Sphaerospora molnari n. sp. (Myxozod, Myxosporea), an agent of gill, skin and blood sphaerosporosis of common carp in Europe. Parasitology 86: 529-535

Lom, J., Pavlaskova, M., Dykova, I. (1985). Notes on kidneyinfecting species of the genus Sphaerospora Thelohan (Myxosporea), including a new species $S$. gobionis sp. nov., and on myxosporean life cycle stages in the blood of some freshwater fish. J. Fish Dis. 8: 221-232

Responsible Subject Editor: W. Körting, Hannover, Germany
Molnar, K. (1984). Experimental evidence that protozoa causing swimbladder inflammation in common carp (Cyprinus carpio) are stage of Sphaerospora renicola. Bull. Eur. Ass. Fish Path. 4: 14-15

Molnar, K. (1988). Development of Myxobilatus legeri in cyprinid fishes. Dis, aquat. Org. 4: 181-187

Ruidisch, S., El-Matbouli, M., Hoffmann, R. W. (1991). The role of tubificid worms as intermediate host in the life cycle of Myxobolus pavlovskii (Achmerov, 1954). Parasitol. Res. 77: 663-667

Shulman, S. S. (1984). Key to determination of parasites to freshwater fish of the fauna of the USSR, Vol. 1. Parasitic protozoa. Nauka Publ., Leningrad (in Russian)

Supamattaya, K., Fischer-Scherl, T., Hoffmann, R. W., Boonyaratpalin, S. (1991). Sphaerospora epinepheli n. sp. (Myxosporea: Sphaerosporidae) observed in grouper (Epinephelus malabaricus). J. Protozool. 38: 448-454

Wolf, K., Markiw, M. E. (1984). Biology contravenes taxonomy in the Myxozod: new discoveries show alternation of invertebrate and vertebrate hosts. Science 225: 1449-1452

Manuscript first received: April 10, 1992

Revised version accepted: July 15, 1992 